\title{
The dynamics and outlook for RMB internationalization
}

\author{
Yonghong, Tu
}

- ReCEIVED: 3 March 2014

- ACCEPTED: 9 JUNE 2014

\begin{abstract}
China's economy grew steadily in 2013. Financial reforms advanced in an orderly manner, policies guiding the cross-border use of the RMB experienced breakthroughs and improvements, and international trade and financial cooperation deepened. In particular, offshore markets developed very rapidly. Five main pillars have come together to push RMB internationalization into the next phase. In the third quarter of last year, the RMB internationalization index (RII) surpassed a level of 1 , heralding the beginning of the RII's single-digit era. Boosted by growing market demand and the release of the "reform dividend", the RMB saw a noticeable increase in its share of use in global markets despite greater exchange rate volatility, hot money arbitrage, and financial turmoil in emerging markets triggered by the tapering Quantitative Easing (QE) in the US. It is estimated that the RII will climb to as high as 1.88 by the end of 2014 .
\end{abstract}

\section{Keywords:}

RMB, China, RMB internationalization index, International trade, Financial cooperation.

JEL classification:

G15, G17, F17. 


\title{
Dinámica y perspectivas de internacionalización del RMB
}

\author{
Yonghong, Tu
}

\section{Resumen}

La economía de China creció de forma sostenida en 2013. Las reformas financieras avanzaron de una manera ordenada, las políticas que guían el uso transfronterizo del RMB también experimentaron grandes avances y mejoras, y se experimentó una notable profundización en el comercio internacional y la cooperación financiera. En particular, los mercados offshore se desarrollaron muy rápidamente. La confluencia de cinco pilares ha impulsado la internacionalización del RMB a la siguiente fase. En el tercer trimestre del año pasado, el Índice de Internacionalización del RMB (RII) superó un nivel de 1, anunciando el comienzo de la era de Rlls de un dígito. El RMB, impulsado por la creciente demanda del mercado y la liberación de los "reform dividends", registró un notable aumento en su cuota de uso en los mercados mundiales a pesar de una mayor volatilidad del tipo de cambio, el arbitraje con dinero caliente y las turbulencias financieras en los mercados emergentes generadas por el estrechamiento de las restricciones cuantitativas (QE) en los EE.UU. Se estima que la RII subirá hasta 1,88 a finales de 2014 .

\section{Palabras clave:}

RMB, China, índice de internacionalización del RMB, comercio internacional, cooperación financiera. 


\section{RMB internationalization}

\subsection{RII Current status and future outlook}

In 2013, the RMB's level of internationalization continued to increase with steady upward momentum. The RII broke through the threshold of 1 to reach 1.20 in the third quarter. It is estimated the RII rose to 1.36 by the end of 2013, a year-on-year increase of $53.61 \%$.

Cross-border trade settlements provided a solid foundation for the internationalization of the RMB. At the end of Q3 2013, RMB cross-border trade settlement transactions performed by banks accumulated to 3.16 trillion yuan, increasing $54.15 \%$ compared with the same period last year, and accounting for $1.95 \%$ of the world total.

RMB-denominated international financial payments strengthened further. Both global credit and bond markets witnessed a further expansion of RMB use, with totals reaching 915.221 billion yuan and 66.409 billion US dollars respectively. RMB direct investment, including foreign direct investment (FDI) and outward direct investment (ODI), accumulated to at total of 137.66 billion yuan. By the end of Q3 2013, the "comprehensive global ratio"1 of RMB-denominated international financial payments reached $1.38 \%$, a year-on-year rise of $66.40 \%$.

More countries are expected to include the RMB in official reserves. The People's Bank of China (PBOC) has successively signed bilateral currency swap agreements with the central banks of Hungary, Albania, Iceland and the UK in 2013. As of the end of Q3 2013, the total amount of currency swap agreements signed between the PBOC and 23 countries and regions reached 2.22 trillion yuan. This not only facilitates RMBdenominated settlement in trade and investment deals, but also helps the RMB to accumulate its strength in international foreign exchange reserves.

In 2014 China enters a crucial phase for comprehensively deepening reforms. Streamlining administration and delegating power as well as finance and tax system reform create a dynamic trend that is stimulating private investment. The new urbanization plan will help to stimulate consumption demand, and in advanced economies demand for imports is recovering. It is expected that China's economy will maintain stable and steady growth. Because China's trade and capital surpluses will not reverse, any violent fluctuation in the RMB exchange rate is unlikely. The willingness to

\footnotetext{
1 The "comprehensive global ratio" of RMB-denominated settlements in global financial markets consists of the proportion of RMB credit in total global foreign credit, the proportion of RMB bonds and bills in the total global issuance of bonds and bills (balance), and the proportion of RMB direct investment in total global direct investment.
} 
use and the real demand for RMB in international economic transactions are both expected to rise. It is estimated that by the end of 2014 the RII will surge to 1.88 .

\section{Figure 1. Evolution of RII}

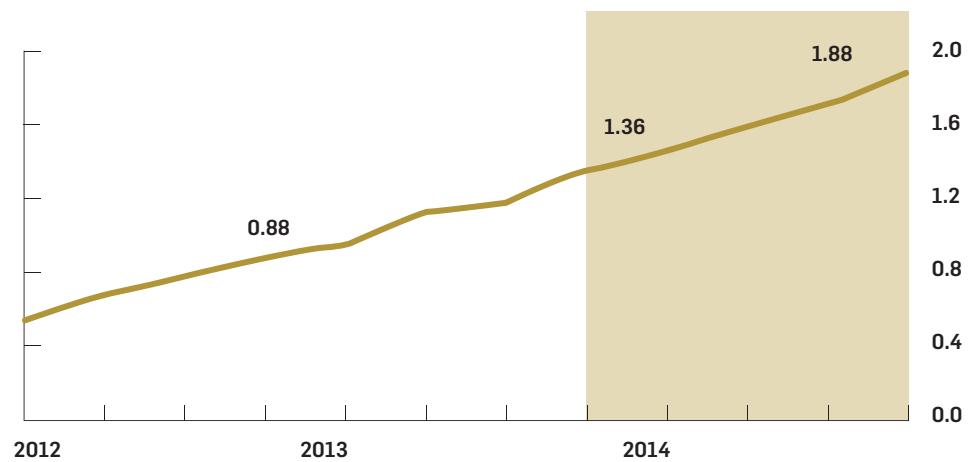

Figure 2. Use of RMB in global trade and financial transactions.

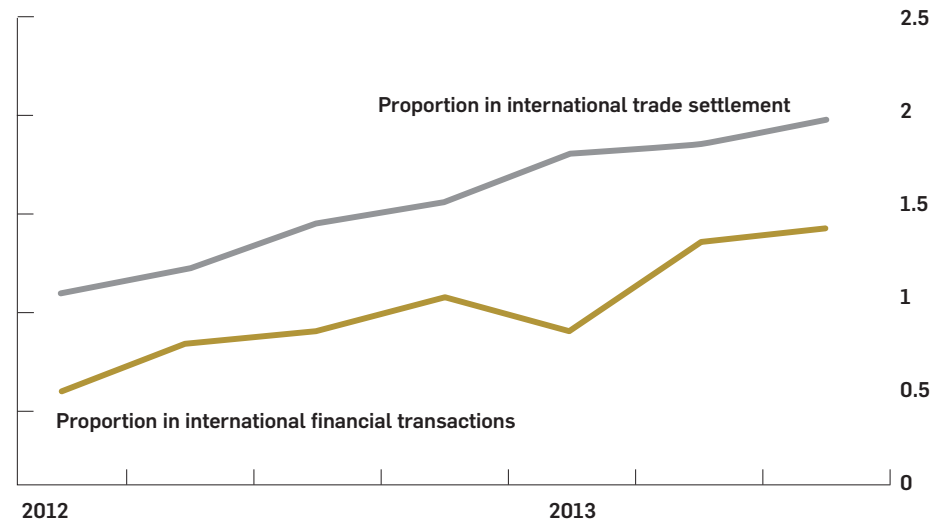

Figure 3. Size of currency swaps between People's Bank of China (PBOC) and other monetary authorities (Unit: Hundred Million RMB)

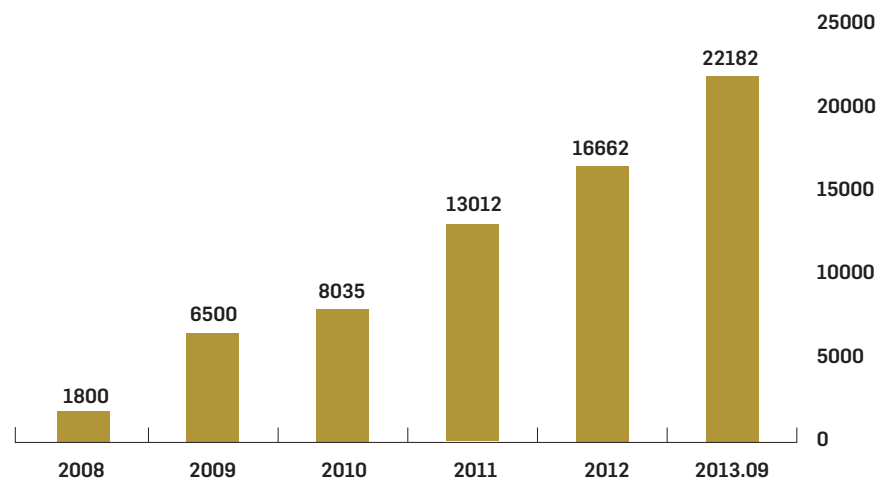




\section{Growth of RII}

First, Chinese economic growth is stable. Trade and investment are increasing rapidly, which consolidates the economic basis for RMB internationalization.

Second, orderly financial system reform is underway. Controls over financial institution loan interest rates are being lifted, RMB Treasury bond futures are reemerging and the RMB Qualified Foreign Limited Partner (RQFLP) program was unveiled. In particular, The China (Shanghai) Pilot Free Trade Zone is the most recent benchmark for opening up that will release huge "reform dividends" and greatly boost the confidence of international markets to accept RMB.

Third, RMB cross-border use policy is improving and making breakthroughs. The review process for RMB settlement in cross-border trade and financing operations within the current account has been simplified greatly, inspiring businesses and institutions to take initiative and use RMB in foreign exchanges more regularly.

Fourth, international trade and financial cooperation are deepening. China signed a free trade agreement with Switzerland and also reached a consensus with BRICS countries to set up a plan for contingency reserves and a broad platform for the international use of RMB.

Fifth, the offshore RMB market has developed rapidly. The scale of offshore RMB deposits in Hong Kong, Taiwan, Singapore, London, Luxembourg, Frankfurt and other places have all increased substantially. Outside of transactions in loans and deposits, CES China 120 Index Futures, RMB Euro Commercial Paper (ECP) and other financial products in RMB have begun trading in offshore markets, further enhancing the international attractiveness of the RMB.

\subsection{Future challenges}

The first challenge: a strong new driver of economic growth has yet to materialize. Economic transformation is still a daunting task, and constraints on resources and the environment are increasing. To a certain extent, slowing economic growth will exert a negative influence on the internationalization of the RMB in the short and medium term.

The second challenge: the exit timeframe and intensity of US Quantitative Easing (QE) is still uncertain. Emerging market countries are faced with higher risks from capital outflows and exchange rate fluctuations, and their positions in the international economy and financial system are now more complicated 
and difficult. External shocks may intensify RMB exchange rate fluctuations and will discourage people in the market motivated by interest arbitrage to hold RMB.

The third challenge: there is a discrepancy between the pace of interest rate liberalization and reform of the RMB exchange rate. Significant differences between onshore and offshore prices for RMB greatly stimulate exchange and interest rate arbitrage and divert the planned course of RMB internationalization away from its focus on the real economy

\subsection{Countermeasures and suggestions}

Relevant policies for cross-border use of the RMB have been greatly improved and various channels for capital flows have been established. In particular, investment and financing products in RMB have been gradually diversified, and the process and procedures for account settlement have been made more convenient. Individuals and enterprises can take full advantage of the low RMB interest rate in offshore markets to effectively allocate resources and reduce investment and financing costs. Furthermore, it is suggested that more attention be paid to the recent change in the RMB exchange rate to bi-directional fluctuations. Appropriate work should be done to hedge against foreign exchange risks.

Following the increased level of RMB internationalization, offshore financial markets may become an important location for transnational corporations to allocate RMB capital. It is suggested that Chinese financial institutions seize this opportunity to speed up the pace of going out into global markets, strengthen efforts to innovate the cross-border trade of RMB, bridge the gap between Chinese and foreign financial institutions and upgrade international competitiveness.

A number of reforms including liberalization of the capital account implemented by the China (Shanghai) Pilot Free Trade Zone put a higher demand on monetary policy authorities and financial regulators to provide institutional support for RMB internationalization. At present it is suggested that close attention be paid to reforming financial institutions, setting a clear path for the interest rate system as soon as possible, to establishing linkages between the interest rate and exchange rate and to allowing the market play a decisive role in the pricing of the RMB. At the same time, in-depth research into the problem of how to effectively protect national industries related to national security and core competitiveness and how to effectively prevent systemic financial crisis should be conducted during the process of opening to the outside. 
2013 witnessed strong momentum in the world economic recovery. The US economy experienced better than expected growth and began to taper QE, causing the US dollar to make a strong return. The eurozone did not escape its economic troubles, and the scale of euro use in trade and financial transactions dropped off. Vigorously stimulated by "Abenomics", Japan's trade surplus expanded and the internationalization of the yen has remained static since 2012. The pound sterling internationalization index declined slightly due to persistent concerns about the British economy.

\section{US Dollar}

In 2013, the US economy maintained a weak recovery but saw overall better than expected economic growth with improvement in employment, recovering consumption and rapid growth in private investments and exports. The tapering of QE by the Fed caused global capital to accelerate the return to the US market, further boosting the demand for the US dollar. In addition to continuous expansion in international credit and bonds, as of the end of the third quarter official reserves held in dollars made up as much as $61.44 \%$ of global reserves, further consolidating the international position of the dollar. It is estimated that the internationalization index of the dollar reached 52.90 by the end of 2013, and will rise $3.38 \%$ year-on-year in 2014 to amount to 54.69 .

\section{Euro}

Uncertainty persists in the eurozone because heavy debt and financial segmentation still constrains economic growth. Economic development among the different countries in the region is slow and unbalanced. The sovereign debt ratings of several countries including France were downgraded while the euro exchange rate has become more volatile. By the end of the Q3 2013, the euro performed poorly in international securities and credit market transactions, markets where it once traditionally enjoyed an advantage, and the scale of euro-denominated transactions was subpar. There was an overall drop in the euro's international position and power, falling short of earning its desired market share. The international index of the euro is estimated to be 24.05 in 2013 and will be 24.13 in 2014, a modest rise of $0.33 \%$ compared with the same period of the previous year.

\section{Japanese Yen}

Under the economic stimulus of "Abenomics", the yen devalued greatly, positively influencing a rally in the Japanese stock market, expanding exports, and restoring business confidence to an extent. During Q3 2013 Japan's outward direct investment (ODI) increased significantly, driving the outflow of yen capital. However, the 
domestic economy has shown signs of pulling back from previous heights. Diplomatic and policy frictions with Japan's neighboring countries have been on the rise, hurting the confidence of international markets and weakening the safe haven status of the yen. The share of yen in international bonds, credit and official reserves have all been on the decline. Considering that positive and negative aspects have essentially maintained a balance it is estimated that the international yen index will reach 4.52 in 2013 and 4.50 in 2014, 0.44 percent decrease year-on-year.

\section{British Pound}

Following an economic recovery in the UK, the pound sterling's function as a safe haven currency was enhanced, and the pound became more prominent in international bond markets. However, the UK maintains relatively strong economic linkages with the eurozone, and background problems there should not be ignored. Exports are weak, there is a lack of investment in enterprises, and manufacturing output and orders still have not returned to pre-crisis levels. It is estimated that the international index of the pound will reach 4.22 in 2013 and 4.19 in 2014, 0.71 percent decrease year-on-year.

\section{Table 1. Overview of the internationalization index predictions for major}

\section{currencies}

\begin{tabular}{|c|c|c|c|c|c|}
\hline & \multirow[t]{2}{*}{2012} & \multicolumn{4}{|c|}{2013} \\
\hline & & Q1 & Q2 & Q3 & Q4 \\
\hline USD & 52.60 & 52.69 & 55.02 & 53.72 & 52.90 \\
\hline Euro & 27.65 & 24.89 & 25.17 & 24.14 & 24.05 \\
\hline Yen & 4.52 & 4.10 & 4.44 & 4.53 & 4.52 \\
\hline Pound & 4.00 & 4.68 & 4.22 & 4.09 & 4.22 \\
\hline
\end{tabular}

\begin{tabular}{|c|}
\hline 2014 \\
\hline 54.69 \\
\hline 24.13 \\
\hline 4.50 \\
\hline 4.19 \\
\hline
\end{tabular}

Figure 4. Internationalization index of major currencies

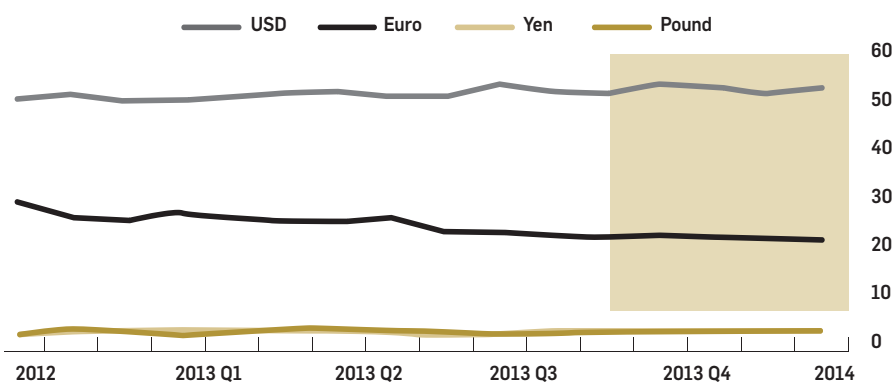

\begin{tabular}{ll|l|l|l|l|l|l|} 
& & & & & & & \\
\hline 2012 & 2013 Q1 & 2013 Q2 & 2013 Q3 & 2013 Q4 & 2014
\end{tabular}

